\title{
Dolphins and African apes: comparisons of sympatric socio-ecology
}

\author{
Maddalena Bearzi ${ }^{1}$, Craig B. Stanford ${ }^{2}$ \\ ${ }^{1}$ Ocean Conservation Society, P.O. Box 12860, Marina del Rey, CA 90292, USA, mbearzi@earthlink.net,www. \\ oceanconservation.org (corresponding author) \\ ${ }^{2}$ Departments of Anthropology and Biological Sciences, University of Southern California, Los Angeles, CA 90089- \\ 0032,USA,stanford@almaak.usc.edu
}

Key words: sympatry, convergence, resource partitioning

\begin{abstract}
Dolphins and African apes are distantly related mammalian taxa that exhibit striking convergences in their socioecology. In both cetaceans and African apes, two or more closely related species sometimes occur in sympatry. However, detailed reviews of the ways in which sympatric associations of dolphins and apes are similar have not been done. As field studies of dolphins and apes have accumulated, comparisons of how the two groups avoid direct food competition when in sympatry have become possible. In this paper we review sympatric ecology among dolphins and African apes, and examine convergences in species-associations in each taxa. We review evidence for hypotheses that seek to explain avoidance of food competition, and consider whether ape-dolphin similarities in this area may be related to the way in which social groups in both taxa optimally exploit their food resources.
\end{abstract}

\section{Contents}

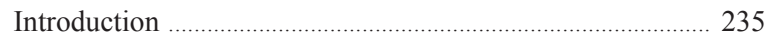

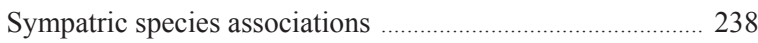

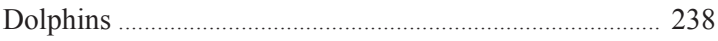

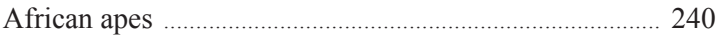

Ecological separation within African ape and dolphin communities .......................................................... 242

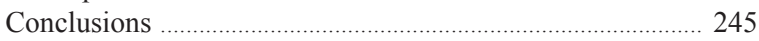

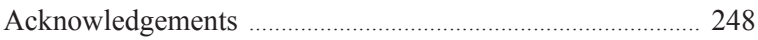

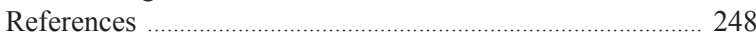

\section{Introduction}

Dolphins and African apes are two distantly related mammalian taxa that have produced socially complex, large-brained nonhuman animals. Comparisons between the two taxa have burgeoned in recent years, as field data on the various species in each group have accumulated. These comparisons have tended to stress parallels between two African apes (Pan troglodytes and P. paniscus) and dolphins (order Cetacea, suborder Odontocetes, family Delphinidae) in brain and social cognition (Herman, 1980; Marino, 1998; McCowan et al., 2000; De Waal and Tyack, 2003; Johnson and Herzing, 2006, Lefevbre et al., 2006), evidence for cultural traditions (Smolker, Richards, Connor, Mann, and Berggren, 1997; Whiten, et al., 1999; Rendell and Whitehead, 2001, Whitehead et al., 2006), and the influence of ecology on social structure (Connor, Read, and Wrangham, 2000b; Connor, Heithaus, and Barre, 2000c; Anderson et al., 2005). Similarities in the pattern of sympatric associations between the two taxa have not been described, even though chimpanzees, bonobos and some well-studied dolphin species (e.g., bottlenose dolphins Tursiops truncatus, spinner dolphins, Stenella longirostris) share many characteristics of their socioecologies: fission-fusion polygamy, male coalitions, strong mother-son bonds, and dispersed foraging for high-quality, patchy food resources (Table 1).

Dolphins and African apes both exhibit sympatric species associations. Chimpanzees and gorillas (Gorilla gorilla) are broadly sympatric across equatorial Africa, and several field studies have examined the way in which these two apes exhibit ecological overlap and potentially partition resources and habitat use (Jones and Sabater-Pi, 1971; Tutin, 1996; Stanford and Nkurunungi, 2003; Yamagiwa and Basabose, 2006). Although the earliest studies of each ape species seemed to show stark interspecific contrasts (e.g., Goodall, 1986; Fossey and Harcourt, 1977), more recent work has blurred some of these distinctions by providing much evidence of intraspecific variability between both species, especially gorillas (Doran and McNeilage, 1998). Detailed field studies of dolphins have lagged behind those of African apes, largely due to the logistical difficulties of observation in a marine 
Table 1. Parallels between dolphins and African apes.

\begin{tabular}{|c|c|c|c|c|}
\hline Trait & Dolphins & References & Primates & References \\
\hline \multirow[t]{4}{*}{ fission-fusion } & \multirow[t]{4}{*}{ Tursiops truncatus } & Würsig, 1978 & \multirow[t]{2}{*}{ P. troglodytes } & Goodall, 1986 \\
\hline & & \multirow[t]{3}{*}{ Wells et al., 1987} & & Wrangham et al., 1994 \\
\hline & & & P. paniscus & Kano, 1992; \\
\hline & & & & Furuichi, 1987 \\
\hline large testes & T. truncatus & Wells et al., 1987 & P. troglodytes & Harcourt, 1978 \\
\hline \multirow[t]{4}{*}{ promiscuous mating system } & \multirow[t]{3}{*}{ T. truncatus } & \multirow{3}{*}{$\begin{array}{l}\text { Connor et al., 2000b } \\
\text { (for general review) }\end{array}$} & P. troglodytes & Goodall, 1986 \\
\hline & & & & Tutin, 1979 \\
\hline & & & P. paniscus & Furuichi, 1987 \\
\hline & Stenella longirostris & Perrin and Mesnick, 2003 & & Sussman, 1984 \\
\hline \multirow[t]{2}{*}{ rival male aggression } & \multirow[t]{2}{*}{ T. truncatus } & \multirow{2}{*}{$\begin{array}{l}\text { Connor et al., 2000abc } \\
\text { (for general review) }\end{array}$} & P. troglodytes & Goodall, 1986 \\
\hline & & & G. gorilla & Fossey and Harcourt, 1977 \\
\hline \multirow{2}{*}{$\begin{array}{l}\text { male dominance } \\
\text { over females }\end{array}$} & \multirow[t]{2}{*}{ T. truncatus } & \multirow[t]{2}{*}{ Samuels and Gifford, 1997} & P. troglodytes & Goodall, 1986 \\
\hline & & & G. gorilla & $\begin{array}{l}\text { Fossey and Harcourt, } 1977 \\
\text { Harcourt et al. } 1981\end{array}$ \\
\hline \multirow{7}{*}{$\begin{array}{l}\text { co-ordinated prey capture } \\
\text { prey capture }\end{array}$} & \multirow{5}{*}{ Tursiops spp. } & Bel'kovich et al., 1991 & \multirow[t]{7}{*}{ P. troglodytes } & Goodall, 1986 \\
\hline & & Tayler and Saayman, 1972 & & Stanford, 1998 \\
\hline & & Acevedo-Gutierrez, 1997 & & \\
\hline & & Norris and Dohl, 1980 & & \\
\hline & & Würsig, 1986 & & \\
\hline & Orcinus orca & Baird and Whitehead, 2000 & & \\
\hline & S. longirostris & Benoit-Bird and Au 2003 & & \\
\hline large brain/ body size ratio & T. truncatus & Marino, 1998 & $\begin{array}{l}\text { P. troglodytes, } \\
\text { G. gorilla, } \\
\text { P. paniscus }\end{array}$ & Dunbar, 1988 \\
\hline cultural transmission & Odontocetes & Rendell and Whitehead, 2001 & P. troglodytes & Whiten et al., 1999 \\
\hline
\end{tabular}

habitat (Bearzi, 2003). The existing literature contains numerous accounts on the biology and ecology of different species of dolphins worldwide, but only a few sympatric populations of small odontocetes have been well investigated in the field (Table 2a).

In this paper we compare the sympatric ecology of dolphins with that of African apes. By sympatry, we mean the co-occurrence of two or more ape or dolphin species in the same immediate habitat, which might be called direct sympatry, where broad sympatry simply means two or more species occur over the same wider geographic area (Futuyma, 1997). The implication of direct sympatry is that the species in question must subsist on the same resource base. According to the ecological principle of competition and mutual exclusion, without some form of resource partitioning one species or the other would eventually be driven to local extinction. By taxa we mean forms that are genetically and morphologically distinct. Among dolphin species there is some controversy as to weather some species consisting of multiple forms should be regarded as distinct taxa (e.g., transient and resident orcas, Orcinus orca, were included in this review because the two forms are genetically and morphologically distinct).
We limit the comparison to the African apes because their societies - chimpanzees and bonobos in particular - display social complexity lacking in the social systems of the lesser apes (Reichard, 2003) and orang-utans (Pongo pygmaeus) (Delgado and van Schaik, 2000). Orang-utan sociality has been well demonstrated to be highly restricted by availability of fruit (van Schaik, 2004). The more distantly related gibbons are now known not to be entirely monogamous reproductively, but most of the taxa are socially pair-bonded (Sommer and Reichard, 2000). It is for these reasons that chimpanzees and bonobos in particular have been the focus for using great ape social ecology to reconstruct the possible behaviour of early hominids (Finch and Stanford, 2004; Stanford, 2006). We hope to elucidate parallels in the ways in which the grouping patterns and feeding strategies of largebrained, socially complex mammals may be an evolved response to their environment.

Habitats as dissimilar as tropical forests and oceans appear to have provided some similar ecological context in which natural selection shaped parallel behavioural adaptations. The co-occurrence of two or more closely related species is thought to have been an im- 
Table $2 a$. Field studies of sympatric associations of dolphins.

\begin{tabular}{|c|c|c|}
\hline Species & Site & Reference \\
\hline \multirow{10}{*}{$\begin{array}{l}\text { O. orca } \\
\text { (transient and resident) }\end{array}$} & Eastern north Pacific & Baird, 1994 \\
\hline & & Baird et al., 1992 \\
\hline & British Columbia & Baird and Dill, 1995, 1996 \\
\hline & Vancouver Island & Bigg, 1982 \\
\hline & & Baird and Whitehead, 2000 \\
\hline & British Columbia and Alaska & Barrett-Lennard et al., 1996 \\
\hline & British Columbia and Washington State & Bigg et al., 1987, 1990 \\
\hline & $\begin{array}{l}\text { Coastal British Columbia and } \\
\text { adjacent waters }\end{array}$ & Ford et al., 1998 \\
\hline & British Columbia & Guinet, 1990; Morton, 1990 \\
\hline & Prince William Sound (Alaska) & Saulitis et al., 2000 \\
\hline \multirow[t]{2}{*}{ T. truncatus, T. aduncus } & Indian and western Pacific Oceans & Hale et al., 2000 \\
\hline & $\begin{array}{l}\text { Chinese waters (Taiwan and } \\
\text { south-central China) }\end{array}$ & Wang et al., 2000 \\
\hline \multirow[t]{8}{*}{ Delphinus delphis and D. capensis } & Santa Monica Bay, California & Bearzi, 2005a \\
\hline & southern California Bight & Banks and Brownell, 1969 \\
\hline & eastern north Pacific & Evans, 1975 \\
\hline & & Heyning and Perrin, 1994 \\
\hline & & Rosel, Dizon, and Heyning, 1994 \\
\hline & Californian coast & Hill and Barlow, 1992 \\
\hline & eastern North Pacific and adjacent waters & Leatherwood et al., 1998 \\
\hline & eastern Pacific & Perrin et al., 1985 \\
\hline Lagenorynchus acutus and D. delphis & Scotian Shelf (Nova Scotia) & Gowans and Whitehead, 1995 \\
\hline L. acutus, D. delphis and Globicephala melas & northeastern United States & Selzer and Payne, 1988 \\
\hline \multirow[t]{6}{*}{ Stenella coeruleoalba and D. delphis } & eastern tropical Pacific & Polacheck, 1987 \\
\hline & & Au et al., 1979 \\
\hline & & Au and Perryman, 1985 \\
\hline & Biscay Bay (North-east Atlantic) & Das et al., 2000 \\
\hline & & Hobbs 2004 \\
\hline & south-eastern coast of Spain & Sagarminaga and Cañadas, 1995, 1998 \\
\hline S. coeruleoalba, D. delphis and Grampus griseus & Gulf of Corinth (Greece) & Frantzis and Herzing, 2002 \\
\hline \multirow[t]{5}{*}{ S. longirostris and Stenella attenuata } & Hawaii (eastern tropical Pacific) & Norris and Dohl, 1980 \\
\hline & & Norris et al., 1994 \\
\hline & & Perrin et al., 1973 \\
\hline & & Psarakos et al., 2003 \\
\hline & western tropical Indian Ocean & Ballance and Pitman, 1998 \\
\hline S. longirostris, S. attenuata and T. truncatus & Hawaii & Baird et al., 2001 \\
\hline S. longirostris and Lagenodelphis hosei & Central Philippines & Dolar, 1999 \\
\hline S. attenuata and T. truncatus & Bahamas waters & Herzing and Johnson, 1997 \\
\hline Globicephala macrorhynchus and D. delphis & eastern tropical Pacific & Polacheck, 1987 \\
\hline G. macrorhynchus and T. truncatus & North-eastern Pacific & Norris and Prescott, 1961 \\
\hline G. macrorhynchus and G. griseus & Santa Catalina Island (California) & Shane, 1995 \\
\hline \multirow[t]{5}{*}{ T. truncatus and D. delphis } & Kalamos Island (Greece) & Ferretti et al., 1998 \\
\hline & & Politi, 1998 \\
\hline & & Politi et al., 1998 \\
\hline & & Bruno et al., 2004 \\
\hline & & Bearzi et al. 2005 \\
\hline $\begin{array}{l}\text { T. truncatus, D. delphis, S. coeruleoalba } \\
\quad \text { and Sousa sp. }\end{array}$ & Cape coast of South Africa & Saayman et al., 1972 \\
\hline Orcaella heinsohni and Sousa chinensis & North-east Queensland (Australia) & Parra, 2006 \\
\hline
\end{tabular}

portant ecological influence in hominin evolution (Coppens, 1994) as it has been in many other mammalian taxa. Behavioural, dietary and physiological habitat specializations may have evolved in response to the presence of potential competing species. Reach- ing a greater understanding of similarities and differences between sympatric dolphin associations and those of African apes may provide a new perspective on the evolutionary context of social complexity and intelligence. 
Table $2 b$. Field studies of sympatric associations of African apes. All studies have been conducted in Africa on chimpanzees (Pan troglodytes) and gorillas (Gorilla gorilla).

\begin{tabular}{ll}
\hline Site & Reference \\
\hline Equatorial Guinea & Jones and Sabater-Pi, 1971 \\
Lopé, Gabon (G. g. gorilla) & Tutin and Fernandez, 1984, 1993; Tutin et al., 1997 \\
Ndoki, Republic of Congo & Kuroda et al., 1996; Nishihara, 1992 \\
Kahuzi-Biega, Democratic Republic of Congo (G. g. gorilla) & Yamagiwa et al., 1996; Yamagiwa and Basabose, 2006 \\
Goualougo Triangle, Republic of Congo (G. g. gorilla) & Morgan and Sanz, 2006 \\
Bwindi Impenetrable, Uganda (G. g. beringei) & Stanford, 2001; Stanford and Nkurunungi, 2003 \\
\hline
\end{tabular}

The main goal of this paper is, therefore, to compare similar patterns of multi-species associations in dolphins and African apes. We try to identify important ecological variables, and suggest that there may be specific features of both dolphin and ape socioecologies that select for the large brains and social complexity that characterize both taxa.

\section{Sympatric species associations}

\section{Dolphins}

Far more studies have been conducted of sympatric associations of dolphins than have been done on African apes (Table 2a,b). The dolphin studies, however, have been less systematic due to the difficulties of obtaining data in an aquatic medium. Therefore, ape-dolphin data are not always comparable. In this paper we seek parallels between the two groups, using parameters of evidence that seem appropriate for comparison (e.g., habitat use, diet, et cetera).

The regular presence of bottlenose dolphins along the coastline has made this dolphin one of the best-known cetaceans (e.g., Shark Bay, western Australia: Connor and Smolker, 1985; Connor et al., 1998; the Firth of Tay and Moray Firth, Scotland: Wilson et al., 1993, Wilson, 1995; Sarasota Bay, Florida: Scott et al., 1990; Wells, 1991; Argentine Bay: Würsig, 1978; Croatia, Mediterranean Sea: Bearzi et al., 1999; and in southern California: Weaver, 1987; Hansen, 1990; Weller, 1991; Defran et al., 1999, Bearzi 2005c). Some populations exhibit a fission-fusion grouping pattern where individuals associate in small groups that change more or less frequently in composition (Connor et al., 2000a).

Sympatric species of the genus Tursiops have been described by a few investigators (Table 2). Bottlenose dolphins and Indo-Pacific bottlenose dolphins ( $T$. aduncus) appeared to be in direct sympatry around the Chinese waters of the Penghu archipelago and were frequently observed in mixed schools with other dolphin species (Yang, 1976; Zhou and Qian, 1985). These two species, however, differed ecologically: bottlenose dolphins preferred the coastal and shallow waters of the continental shelf feeding upon benthic or reefdwelling fish and cephalopods whereas Indo-Pacific bottlenose dolphins favored offshore waters feeding mostly on schooling epipelagic and mesopelagic species (Wang et al., 2000).

In the Indian and western Pacific Oceans, Hale et al. (2000) recorded different preferences in habitat choice for the same species, with bottlenose dolphins frequenting both shallow waters and offshore reefs and Indo-Pacific bottlenose dolphins inhabiting estuaries and costal waters. This study showed that some areas were occupied exclusively by one species, with coastal regions of sympatry in their distribution.

Sympatric bottlenose dolphins and Indo-Pacific bottlenose dolphins also exist in south African waters (Wang et al., 2000), although Ross (1977) described these species as being typically allopatric. Ross (1977) noted different prey in their stomachs, with bottlenose dolphins exploiting deep reefs located offshore and Indo-Pacific bottlenose dolphins preferring shallow inshore waters.

Inshore populations of the genus Delphinus have been described for different areas worldwide, including California (Evans, 1975; Bearzi, 2005a), South Africa (Young and Cockroft, 1994), New Zealand (Neumann, 2001ab) and the Mediterranean Sea (Bruno et al., 2004; Bearzi et al., 2005), whereas the ecology of offshore communities remains largely unknown (Evans, 1994). Short-beaked common dolphins (D. delphis) and long-beaked common dolphins (D. capensis) occur sympatrically in tropical and temperate waters (Heyning and Perrin, 1994; Table 2a).

In Santa Monica Bay, California, the direct sympatric ecology of short-beaked common dolphins and 
long-beaked common dolphins was investigated (Bearzi, 2005a). Short-beaked common dolphins and longbeaked common dolphins were sympatric in the bay, but they were never seen in mixed schools (Bearzi, 2005a). The co-existence of these species is probably explained by an abundance of anchovies (Engraulis mordax), among their favorite food, and other prey in areas of local upwelling, as also reported by other authors (Mais, 1974; Evans, 1975; Hui, 1979). These sympatric species had similar diet (Fitch and Brownell, 1968), however, slight differences in their prey were observed (Schwartz et al., 1992). This difference in diet might indicate how partitioning of ecological niches may have reduced the occurrence of competition for food resources when the dolphins were in direct sympatry (Bearzi, 2003, 2005a).

In the same bay, the broad sympatric ecology of bottlenose dolphins, short-beaked common dolphins and long-beaked common dolphins was also investigated (Bearzi, 2005a). High abundance and year-round occurrence of the three species appeared to be correlated to prey abundance and, consequently, to the oceanography of this region (Bearzi, 2005a), as also reported for other small odontocetes in different locations (Cockcroft and Peddemors, 1990; Gowans and Whitehead, 1995; Defran et al., 1999). Eighty percent of bottlenose dolphin sightings $(n=157)$ were found in shallow waters and they were generally separated from the distribution of the two species of common dolphins showing spatial habitat partitioning (Bearzi, 2005a).

Das et al. (2000) reported slightly different dietary preferences for sympatric striped dolphins and shortbeaked common dolphins in the north-east Atlantic (Bay of Biscay). In this area, both species were quite opportunistic feeders taking advantage of seasonally or locally abundant preys, but striped dolphins were observed displaying more opportunistic trophic habits compared to common dolphins (Das et al. 2000).

Habitat partitioning and direct sympatry have been observed for short-beaked common dolphins and other delphinids by Gowans and Whitehead (1995). These authors examined the summer distribution of shortbeaked common dolphins, Atlantic white-sided dolphins (Lagenorhyncus acutus) and long-finned pilot whales (Globicephala melas) in the highly productive waters in and near a submarine canyon of the Scotian Shelf called the Gully. These species were much more abundant inside the Gully than outside, and they used some areas of the Gully slightly differently, showing spatial partitioning of habitat. Atlantic white-sided dolphins and short-beaked common dolphins divided the Gully temporally but not geographically whereas pilot whales ranged widely over the entire study site, preferring locations with flat relief.

Habitat partitioning and direct sympatry were observed for short-beaked common dolphins and bottlenose dolphins in the eastern Ionian Sea near the island of Kalamos (Politi et al., 1998; Bruno et al., 2004). The two sympatric species had adopted different foraging strategies, with common dolphins feeding in the water column or near the surface and bottlenose dolphins focusing on bottom prey (Ferretti et al., 1998). In spite of such sympatry, the two species rarely mixed and showed no direct interactions (Bearzi et al., 2005).

Frantzis and Herzing (2002) observed striped dolphins and short-beaked common dolphins also in mixed-species associations with Risso's dolphins (Grampus griseus). Among the accountable factors for mixed-species associations in the Mediterranean Sea there were: 1) the relative abundance of each species, and 2) the potential dependence of common dolphins on striped dolphins when the former could not form single-species groups (Frantzis and Herzing, 2002).

Two forms of killer whales, resident and transient, are distinguished in the eastern north Pacific (Bigg, 1982; Baird and Dill, 1995). Residents and transients show differences in acoustics, morphology, pigmentation patterns, and genetics (Barrett-Lennard, Ford, and Heise, 1996; Ford et al., 1998; Baird, 2000). Besides significant differences, these populations are well known to live sympatrically (Table 2a).

In British Columbian and Washington waters, two communities of northern and southern resident killer whales live in broad sympatry with transient killer whales while displaying remarkable differences in feeding behaviour (Baird, 2000; Saulitis et al., 2000). Resident populations feed primarily on fish, while transient whales prey on marine mammals, mainly pinnipeds (Bigg et al., 1990; Ford et al., 1998; Saulitis et al., 2000). Bigg et al. (1990) and Ford et al. (1998) observed that resident killer whales of British Columbia, Washington and Alaska ate mostly salmonids, of which $50 \%$ were chinook (Oncorhynchus tshawytscha), the largest and most energy-rich species present year-round in these areas. Similarly, resident killer whales in Prince William Sound, Alaska, fed primarily on coho salmon (Oncorhynchus kisutch), while transient killer whales fed on harbour seals (Phoca vitulina) and Dall's porpoises (Phocoenoides dalli; Saulitis et al., 2000).

In the various study areas, transients travel and forage more than residents $(88.5-94.5 \%$ of their time vs. $58-72 \%$ of the time), whereas residents socialize and 
rest more than transients (Morton, 1990; Felleman et al., 1991; Baird, 1994; Saulitis et al., 2000). Saulitis et al. (2000) also reported that different prey choices among populations of killer whales were accompanied by different foraging strategies. Residents foraged in co-ordinated pods swimming at high speed, lunging, encircling and chasing fish at the surface (Similä and Ugarte, 1993; Barrett-Lennard et al., 1996); mammaleating transients either swam along shorelines or in dispersed formation across open areas (Barrett-Lennard et al., 1996; Saulitis et al., 2000).

Baird and Dill (1995) found high variability in habitat use between resident and transient whales, with transient animals spending far more time in shallow waters. Dissimilarities existed also in diving patterns of these populations, with resident animals spending most of their time in the upper twenty metres of the water column and feeding on salmonids and with transient animals displaying longer mean dive durations between 20-60 m (Bigg et al., 1990; Baird 1994, 2000).

Associations between transient and resident killer whales have rarely been seen (Morton, 1990; Baird and Dill, 1995; Barrett-Lennard et al., 1996). These populations do not associate, most likely because of their strikingly different diet (Ford et al., 1998; Saulitis et al., 2000).

\section{African Apes}

Chimpanzees live in fission-fusion polygynous societies in which members of a community form temporary foraging associations (parties) of varying sizes (Goodall, 1986). This flexible grouping pattern is thought to be a social adaptation to a reliance on patchily distributed fruit trees (Wrangham, 1977), although the energy value of particular fruits varies widely and may play an important role (Conklin-Brittain et al., 2006). Chimpanzee party size and composition varies widely among study sites (Boesch and Boesch-Achermann, 2000; Pruetz, 2006). Party size is thought to correlate with the size and distribution of fruit patches and with the presence of females with sexual swellings (Chapman et al., 1994; Anderson et al., 2005, 2006), but empirical tests that separate these influences are lacking and the relative influences may vary from site to site (te Bockhorst and Hogeweg, 1994). Chimpanzee communities vary in size from 20 to over 100, depending on the site (Nishida, 1979; Mitani and Watts, 1999). Females spend most of their time with their offspring, rarely joining large foraging parties (Goodall, 1986). Estrous females provide an exception to this pattern, being both highly sociable and strongly attractive to males. The chimpanzee diet is mainly ripe fruit ( $70 \%$ of the diet), but their diet includes leaves, shoots, buds, blossoms, seeds, nuts, bark, invertebrates, birds, eggs, honey and a number of mammal species (Wrangham, 1977; Goodall, 1986; Stanford, 1998). The Kasakela chimpanzees of Gombe National Park use at least 141 species of trees and plants (Wrangham, 1977). However, 95\% of feeding time is spent on half of these food types, and foods are selected in proportion to their availability (Wrangham, 1977).

Gorillas occur across a wide range of habitat types, and their ecology varies accordingly (e.g, Robbins et al., 2006). Mountain gorillas (Gorilla gorilla beringei) from the Parc d'Volcans in the Virunga mountains of Rwanda feed primarily on perennially available foliage and other non seasonal foods (Watts, 1984). Fruit comprises a large percentage of western lowland gorilla diets. In Equatorial Guinea, $40 \%$ of the diet was composed of fruit (Jones and Sabater-Pi, 1971; Sabater-Pi and Groves, 1972; Sabater-Pi, 1977). In Cameroon, evidence of fruit was found in $50 \%$ of all fecal samples (Calvert, 1985). Studies in Gabon (Tutin and Fernandez, 1985, 1993; Rogers et al., 1988; Williamson, 1988; Rogers, Maisels et al., 1990; Williamson et al., 1990), the Central African Republic (Remis, 1997; Goldsmith, 1999) and the Republic of Congo (Nishihara, 1992, 1995) indicate a large proportion of fruit in the diet. Although large amounts of fruit are consumed during certain times of the year more than $90 \%$ of the fecal samples contain fiber and leaf fragments (Rogers and Williamson, 1987; Williamson, 1988) and in one study herbaceous material was eaten in equal amounts throughout the year (Goldsmith, 1999).

Gorilla ranging is strongly influenced by habitat and food availability. The day range of Karisoke gorillas is short; over a period of seventeen months a group traveled between 190 and 3,300 $\mathrm{m}$ per day (mean $=$ $570 \mathrm{~m}$; Watts, 1991). Watts found that the effect of group size on time spent feeding is small, which suggests that the costs of social foraging are low for mountain gorillas. Lowland gorillas travel much farther per day. Tutin (1996) found an overall mean day range in Lopé of $1.1 \mathrm{~km} /$ day, while Remis (1994) found a mean at Bai Hokou, Central African Republic, of $2.3 \mathrm{~km} /$ day. Differences between sites may be related to habitat and group size differences.

Lowland gorillas travel significantly farther during periods of fruit availability. Research in Lopé (Tutin, 1996) and at Bai Hokou (Remis, 1997; Goldsmith, 1999) demonstrates that daily ranging behaviour is in- 
fluenced by the degree of frugivory. Tutin et al. (1992) suggest that due to their reliance on terrestrial herbaceous vegetation, western lowland gorilla groups do not experience high levels of within-group feeding competition. As a result, they do not need to modify their group size, explaining why their grouping pattern resembled that of mountain gorillas. At Bai Hokou, however, there was a significant positive relationship between group size and daily path length during all seasons, suggesting high levels of within-group feeding competition. In addition, groups were found to form temporary subgroups that fed and slept separately from one another, perhaps as a way of reducing feeding competition (Remis, 1994; Goldsmith, 1999).

Mountain gorilla group size does not seem to influence day range either due to the widespread, abundant foliage on which they feed (Watts, 1996). Mountain gorillas live in relatively stable groups, and a variable number of offspring. Both male and female mountain gorillas tend to emigrate from their natal groups (Harcourt, 1978). Emigrating males either join all-male bands or travel by themselves; females either join a new breeding group or take up with a solitary male (Stewart and Harcourt, 1987). Harcourt et al. (1981) reported that $60 \%$ of studied groups at Karisoke had only one adult male. Approximately $10 \%$ of the groups were all-male bands (Stewart and Harcourt, 1987). An emerging picture of lowland gorilla social organization is of less cohesive groups that are more likely to contain multiple silverbacks (Tutin et al., 1992; Remis, 1994; Olejniczak, 1996; Goldsmith, 1999). Evidence from Lopé (Tutin et al., 1992), the Ndoki (Olejniczak, 1996), and Bai Hokou (Goldsmith, 1999) suggest a mean group size of about 9.5 individuals, with groups not exceeding 18 individuals. Average group size is larger in eastern lowland gorillas (G. g. graueri) (10.8; Yamagiwa and Basabose, 2006).

There are a small but growing number of detailed ecological studies of sympatric chimpanzee and gorilla populations (Table 2b). Jones and Sabater-Pi (1971) identified several means of ecological separation between the two species in Equatorial Guinea. During the wet season, gorillas ranged in fairly open areas of regenerating vegetation, while chimpanzees utilized the upper strata of primary forest. During the dry season, gorillas were found in dense vegetation at the edge of forests and occasionally in primary forest adjacent to areas of regenerating vegetation, while chimpanzees ranged mainly in the lower strata and on the ground in primary forest. The gorillas in Jones' and Sabater-Pi's study were reported to feed almost com- pletely terrestrially, whereas chimpanzees were mostly arboreal feeders.

More detailed sympatric ecological studies have been conducted in the Lopé Reserve in Gabon, where chimpanzees and gorillas live at similar population densities (Tutin and Fernandez, 1985, 1993). Lowland gorilla diet at Lopé more closely resembles that of chimpanzees than that of mountain gorillas living in the Virungas (Rogers et al., 1990; Tutin and Fernandez, 1993). It appears that Lopé gorillas satisfy a substantial part of their energy needs from fruit, relying on leaves to provide protein (Rogers et al., 1990). Most gorilla plant foods (69\%) are harvested arboreally (Tutin and Fernandez, 1993). Lopé chimpanzees consist of at least 174 food items in their diet, including 111 species of fruit (Tutin and Fernandez, 1993). Approximately $76 \%$ of Lopé chimpanzee plant foods are harvested arboreally (Tutin and Fernandez, 1993). There is great overlap in the diets of chimpanzees and gorillas at Lopé with approximately $60-80 \%$ of foods being eaten by both species (Williamson et al., 1990; Tutin and Fernandez, 1993). Gorillas are more likely to feed on terrestrial herbaceous vegetation than chimpanzees and are more ready than chimpanzees to concentrate on this vegetation when fruit is scarce. Chimpanzee and gorilla diets diverge most when fruit is not abundant, although it is mainly gorillas that shift foraging strategies while chimpanzees continue to forage extensively for ripe fruit even in periods of low fruit availability (Williamson et al., 1990; Remis, 1997). Direct interspecific interference competition has never been observed.

Research on sympatric gorillas and chimpanzees in the Nouabalé-Ndoki forest of the Congo and Central African Republic have revealed similar patterns of resource use. In Nouabalé-Ndoki, gorillas are more highly frugivorous than any other studied population (Kuroda, 1992; Nishihara, 1995). Their diet consists of over $63 \%$ fruit, which is consumed seasonally. Ndoki gorillas make extensive year-round use of swamp forest (Nishihara, 1995) and feed in fig trees in proximity to chimpanzees during times of fruit scarcity (Suzuki and Nishihara, 1992). They also feed extensively on aquatic herbaceous vegetation, perhaps as a fallback food analogous to the use of terrestrial herbaceous vegetation (Magliocca and Querouil, 1997).

Eastern lowland gorillas and chimpanzees are sympatric in Kahuzi-Biega National Park in eastern Democratic Republic of Congo (Yamagiwa et al., 1994; Yamagiwa et al., 1996). Gorillas occur there at a much higher density than chimpanzees. The higher popula- 
tion density of gorillas may have been related to the chimpanzee frugivorous diet in a mountainous area of low fruit diversity. Yamagiwa et al. (1996) found that gorillas ate a more diverse diet than chimpanzees did. Both species ate fruit over the entire annual cycle, though not necessarily the same species at the same time. They shared at least four important fruit species in their diets and both apes sometimes fed together in the same tree crown. Gorillas found at lower elevations in Kahuzi-Biega ate more fruit than those at higher elevations, apparently related to fruit availability differences (Yamagiwa et al., 1994). Ecologically, this population appears to be intermediate between western lowland and mountain gorilla populations in the degree of frugivory and the plant species diversity in the diet.

Results of the Bwindi Impenetrable Great Ape Project include the first detailed study of Bwindi gorilla feeding and ranging ecology (Nkurunungi, 2005) and preliminary information on Bwindi chimpanzee behavioural ecology (Stanford, 1999; Stanford and Nkurunungi, 2003). Bwindi gorilla diet is seasonally high in fruit; in some months more than $50 \%$ of gorilla dung samples contain seeds (Nkurunungi, 2005). In other months, however, the gorilla diet contains no fruit and is similar to the diet of gorillas in the Virungas (Watts, 1984; Stewart and Harcourt, 1987). Gorilla and chimpanzee diets are thus similar in some months, and chimpanzees range farther when fruit is scarce to find fruit. Day range is positively correlated with the percentage of fruit in the diet, although only slightly so. Bwindi gorillas are much more likely to construct nests in trees than their Virungas counterparts, who nest entirely on the ground (Nkurunungi, 2005).

\section{Ecological separation within African ape and dol- phin communities}

Two closely related, ecologically similar species that share one habitat are presumed to have either diverged from each other in the course of their evolution or else are currently in ecological competition that may lead eventually to the local extinction of one species. This is based on an assumption that the two species are resource-limited. But are African apes and dolphins resource-limited?

Evidence from studies of African apes suggests that they are. Kuroda et al. (1996) found that chimpanzees and gorillas in the Ndoki forest practice mutual avoidance, although they occasionally enter the same food trees. Findings that chimpanzee and gorilla diets converge most when fruit and foliage are most abundant indicate that there is some degree of ecological release during times of food abundance (Tutin and Fernandez, 1993; Stanford and Nkurunungi, 2003). Gorillas are likely able to make use of herbaceous foliage as fall back food when fruit is not available, accounting for the dietary divergence in times of food scarcity.

The food limitation question for dolphins is more complicated due to the difficulties of observing animals in the open ocean and obtaining direct evidence of food prey intake. Similar species co-occuring in the same area are thought to compete for resources unless they occupy different physical locations and/or feed on different prey (Roughgarden, 1976; Pianka, 1978). Sympatric species of odontocetes observed worldwide and living in a restricted region where food is limited were reported to adopt a few similar strategies. These strategies include foraging and feeding at different depths and/or inhabiting shallow and deep waters (Saayman et al., 1972; Norris et al., 1994; Baird and Dill, 1995; Ferretti et al., 1998; Wang et al., 2000; Hobbs, 2004; Bearzi, 2005a; Parra 2006) and divergence in diet (Bigg et al., 1990; Ferretti et al., 1998; Baird, 2000; Das et al., 2000; Hale et al., 2000; Saulitis et al., 2000).

Different dolphin species can be found together in the same microhabitat showing prey resource partitioning and, apparently, no competition for resources (Selzer and Payne, 1988; Gowans and Whitehead, 1995; Bearzi, 2005a,b). In these situations where diets frequently overlap, it appears that sympatric species can differ slightly in prey preferences (Gowans and Whitehead, 1995). Many species of odontocetes, such as common dolphins, are well known to be opportunistic feeders that can vary their diet according to the availability of the most abundant and catchable prey (Evans, 1975, 1994; Klinowska, 1991). A small difference in prey preference may be enough to support the feeding requirements of more than one species, allowing them to co-exist (Hoelzel, 1998).

Similar patterns in the sympatric associations of some dolphin species and African apes are outlined in Table 3. As can be seen, ecological separation exists between sympatric species in both taxa based on microhabitat, ranging patterns, and diet.

In all forests in which both chimpanzees and gorillas have been studied, chimpanzees forage at greater heights than gorillas. Although chimpanzees in Bwindi eat far more tree fruits than gorillas do, gorillas forage in the same fruit trees seasonally and also forage high 
in trees for epiphytic plants and fungi. Chimpanzees nest at significantly higher forest heights than gorillas do in all months (Stanford and Nkurunungi, 2003). Does competition exist for nesting sites? There is little evidence of this, although two pieces of information are suggestive. First, in the northern section of the study site, the only area of the national park in which gorillas do not occur, chimpanzees nest on the ground at a higher frequency than noted elsewhere. Second, when gorillas nest in trees, they nearly always choose one species, an understory tree that is rarely used as a nest tree by chimpanzees.

Some dolphin species seem to use strategies similar to chimpanzees and gorillas but in an aquatic medium. Foraging at different heights in the forest canopy can be compared with foraging at different depths in the ocean.

A separation of niches based on depth was proposed in the eastern Ionian Sea (Ferretti et al., 1998; Politi et al., 1998). Sympatric species can also display ecological separation utilizing inshore and offshore waters, as observed by Wang et al. (2000) for bottlenose dolphins living in Chinese waters, Dolar (1999) for spinner dolphins (Stenella longirostris) and Fraser's dolphin ( $\mathrm{La}$ genodelphis hosei) in the Sulu Sea, Bearzi (2005a) for bottlenose dolphins in sympatry with short-beaked common dolphins in California waters, and Baird and Dill (1995) for transient and resident killer whales in British Columbia and Washington State. These killer whales also show different diving patterns (Bigg et al., 1990; Baird 1994, 2000).

Chimpanzees and gorillas can occupy the same home ranges and eat overlapping diets but nevertheless harvest their foods differently in ways that may mitigate competition (Morgan and Sanz, 2006). As Yamagiwa (1996) has pointed out, a chimpanzee community uses its home range on a regular basis, traveling to all parts of a range up to $30 \mathrm{~km}^{2}$, but they canvass it only seasonally, remaining in one small part of the overall range for long periods. Gorillas may be able to forage this way because of their reliance on leafy herbaceous plants, which are more densely and evenly distributed on the landscape than the ripe fruits for which chimpanzees forage (Malenky et al., 1994).

Small odontocetes with overlapping diet in the Gully (Scotian Shelf) occupy the same home ranges in their daily activities but in a slightly different way (Gowans and Whitehead, 1995). Resident and transient killer whales also use the same habitat in British Columbia and Washington State but with different travel routes, sometimes related to the bottom topogra- phy (Morton, 1990; Felleman et al., 1991; Gowans and Whitehead, 1995; Baird, 2000). Dietary separation of day and/or during different seasons was observed for Atlantic white-sided dolphins and short-beaked common dolphins in the Gully (Gowans and Whitehead, 1995) and for spotted dolphins and spinner dolphins in the eastern tropical Pacific (Perrin et al., 1973; Norris and Dohl, 1980; Norris et al., 1994; Scott and Cattanach, 1998).

Chimpanzees and gorillas have different diets in the wild, although the degree of difference varies among study sites (Fig. 1b). At all sites where they have been studied, chimpanzees are ripe fruit specialists, traveling long distances in search of new fruit sources. Gorillas, based on Fossey's early work, were thought to be obligate folivores. More recent fieldwork on other gorilla populations living at lower elevations has revealed gorillas to be opportunistic, feeding heavily on fruits when available while using foliage as a fallback food during times of food scarcity (Tutin, 1996). In Bwindi, gorilla and chimpanzee diets converge during periods of heavy fruiting, and the two species share many of the same preferred food species. During times of scarcity, chimpanzees scatter into smaller social units to forage further afield for fruits while gorillas turn to fallback foods, primarily herbaceous groundcover.

Sympatric species of dolphins show different diets with a degree of dissimilarities among study areas. Hale et al. (2000) report different preferences in prey for sympatric species of bottlenose dolphins for various areas around the world, and Das et al. (2000) give an account of different diet for striped dolphins and short-beaked common dolphins in association with albacore tuna in the north-east Atlantic (Bay of Biscay).

The most striking example of diet divergence is known for resident and transient killer whales (Bigg et al., 1990) and individual populations of this species also specialize in catching specific types of prey (Fig. 1a, Felleman et al., 1991). Like gorillas, many species of odontocetes are opportunistic feeders, able to change their diet based on food availability (Klinowska, 1991). Transient killer whales in Prince William Sound feed almost evenly on harbour seals (Phoca vitulina) and Dall's porpoises (Phocoenoides dalli), while off British Columbia and south-eastern Alaska, harbour seals are their most favored prey (Saulitis et al., 2000). Off southern Vancouver Island, Baird (1994) reported that transient killer whales killed harbour seals almost exclusively. Attacks by transient killer whales on Dall's porpoises appeared to be more energetically expensive and less successful. These 

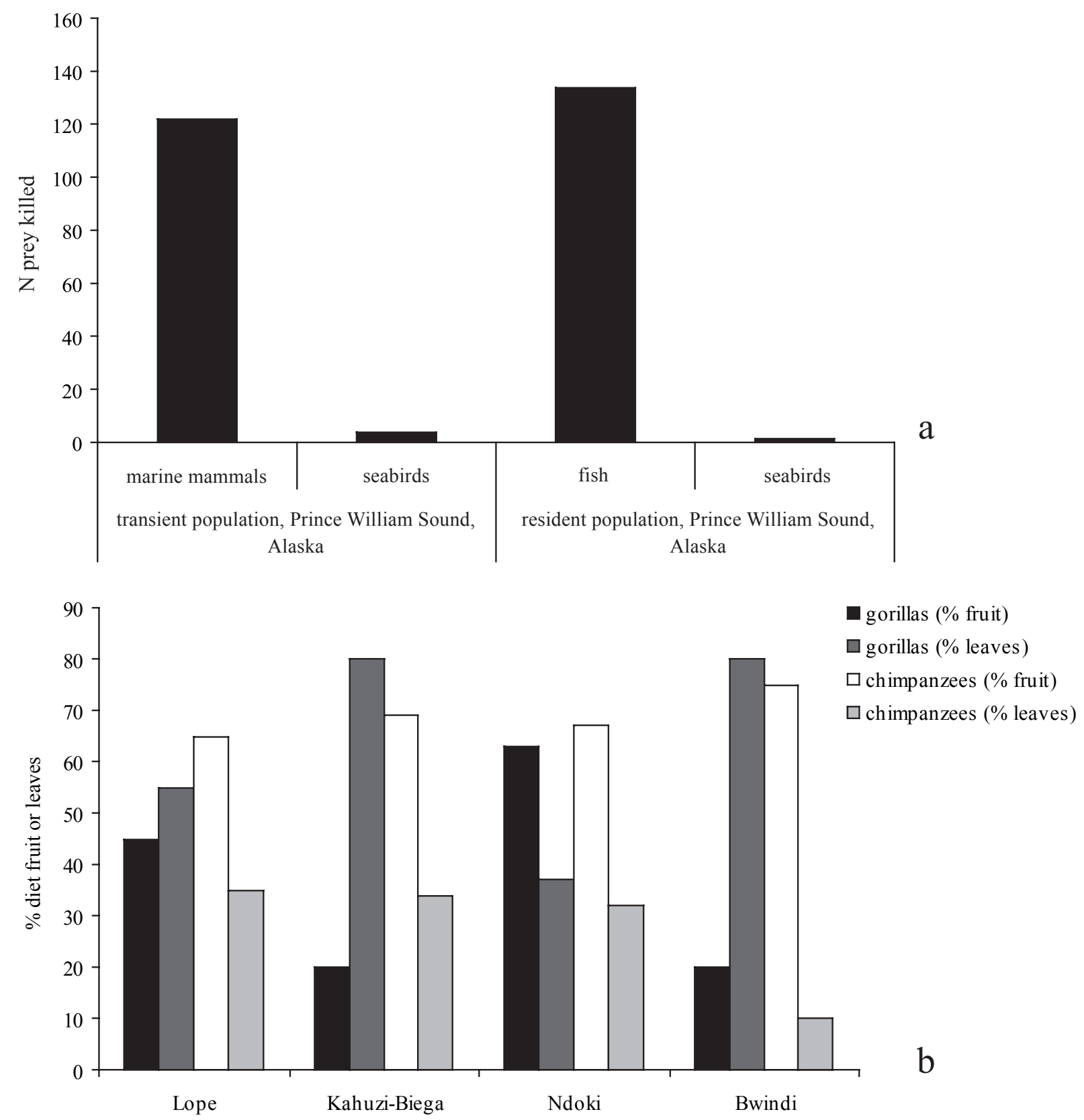

Figure 1a, $b$. Examples of dietary differences for odontocetes and pongids.

a. Diet of transient and resident populations (Ford et al., 1998).

b. Comparison of gorilla and chimpanzee diets at four sites in which the two species are sympatric (Lopé: Tutin and Fernandez, 1993; Tutin et al., 1997; Kahuzi-Biega: Yamagiwa et al., 1996; Ndoki: Kuroda et al., 1996; Bwindi: Stanford and Nkurunungi, 2003).

differences in transient killer whales' preferential preys in Prince William Sound in comparison with those of British Columbia, Washington and Alaska may been explained by the fact that the former loca- tion has a lower number of pinnipeds than the latter locations.

Direct competition and aggressive behaviour between sympatric species of the family Delphinidae has 
occasionally ever been observed (Shane, 1995; Ross and Wilson, 1996; Baird, 1998; Patterson et al., 1998; Frantzis and Herzing, 2002; Herzing et al., 2003; Psarakos et al., 2003).

Ross and Wilson (1996) witnessed four violent dolphin-porpoise interactions in the Moray Firth, Scotland, but these authors did not discuss possible reasons for these interactions. In the same study area, Patterson et al. (1998) recorded aggressive behaviour by sympatric bottlenose dolphins toward harbour porpoises, suggesting that infanticide may be a factor responsible for this type of behaviour. Baird (1998) also reported aggressive behaviour by a Pacific white-sided dolphin on a neonatal harbour porpoise in Washington State. His study showed that aggression was more the result of an object-oriented play than aggressive behaviour displayed by one species competing for food, mate, or space. In the western edge of Great Bahama Bank, Herzing et al. (2003) observed interspecific interactions between Atlantic spotted dolphins (Stenella frontalis) and bottlenose dolphins, with male spotted dolphins displaying dominant mounting behaviour towards bottlenose dolphin males. In Hawaiian waters, Psarakos et al. (2003) also observed aggressive behaviour between sympatric spinner and spotted dolphins. This type of interaction was accompanied by interspecific copulation. It is clear that by contrasting these occasional examples of interactions, the majority of the investigations conducted worldwide to date show that dolphins under limited food resources conditions tend, whenever possible, to avoid direct competition by using behavioural, dietary and physiological habitat specializations (Table 3 ).

Researchers have long questioned whether gorillas and chimpanzees in sympatry engage in contest food competition. Kuroda et al. (1996) inferred mutual avoidance from the infrequency with which the two species met in the forest despite similar densities and ranging patterns. Although data from Bwindi do not provide systematic evidence of contest food competition, Stanford (pers. obs.) has witnessed one obvious incident, in which a party of nine chimpanzees occupied a fruiting tree, displaying at a gorilla group that attempted to ascend the same tree. The observation that chimpanzees were ecologically dominant, at least in this one encounter, accords with other recent studies of sympatric primates, in which two species assume role of ecological subordinate and dominant (Houle, 2004). Stanford and Nkurunungi (2003) also recorded gorillas and chimpanzees nesting in adjacent trees on the same night, and the home ranges of the gorilla study group and the chimpanzee study community occupied roughly the same area of forest. Rather than direct competition, most sympatric chimpanzee-gorilla associations may partition food resources by having different key food preferences, and through the seasonality of their diets (Stanford and Nkurunungi, 2003). In this way African ape sympatry would resemble sympatric dolphins.

\section{Conclusions}

Do sympatric associations among dolphins and African apes reflect convergently evolved social adaptations?

The pattern of ecological divergence described above can be found in a wide variety of associations among terrestrial or marine animals. The most striking ecological parallel between the two taxa is the tendency toward a fission-fusion grouping pattern, in which proximate changes in group size and composition appear to reflect proximate availability and distribution of food resources. The key food resource that may account for this grouping structure in primates is ripe fruit, the occurrence of which is ephemeral and patchy. This pattern is seen in only a few primate species, and in very few non primate mammals. In addition to chimpanzees, bonobos (Pan paniscus; Kano, 1992) and spider monkeys (Ateles sp.; Symington, 1987) most prominently exhibit fission-fusion. Such a social system may, among other functions, enable the animals to forage for widely dispersed, frequently changing food sources, and to cope with the complexities of group life that follow from such a fluid foraging pattern. In these respects, many dolphin species (e.g., bottlenose dolphins, killer whales, common dolphins, spinner dolphins) offer a striking parallel to chimpanzees and bonobos. If fission-fusion grouping is a response to a complex foraging environment and has placed intelligence and social complexity at a premium in these two distantly related taxa, how may it have affected sympatric associations in the two groups?

Among African apes, sympatry between chimpanzees and gorillas has only recently been studied in detail. In sympatric association with gorillas, chimpanzees utilize many of the same food resources in a different manner, foraging widely on a daily basis while sympatric gorilla group forage more slowly within a smaller area while remaining in cohesive groups. Since these two species and their ancestors have presumably been broadly sympatric for millions of years, 
Table 3. Parallels between sympatric associations of dolphins and African apes.

\begin{tabular}{|c|c|c|}
\hline Trait & Species and Locations & References \\
\hline different habitat use & dolphins & \\
\hline Shallow vs. deep waters and/or & O. orca (transients and residents) & Baird and Dill, 1995 \\
\hline inshore vs. offshore populations & British Columbia and Washington State & Baird, 1994, 2000 \\
\hline & $\begin{array}{l}\text { D. delphis, D. capensis and T. truncatus } \\
\text { Santa Monica Bay, California }\end{array}$ & Bearzi, 2005a \\
\hline & D. delphis, T. truncatus & Ferretti et al., 1998, \\
\hline & Kalamos Island, Greece & Politi et al., 1998 \\
\hline & D. delphis, S. coeruleoalba & Hobbs, 2004 \\
\hline & Western English Channels, Bay of Biscay & \\
\hline & $\begin{array}{l}\text { T. truncatus, T. aduncus } \\
\text { Chinese waters }\end{array}$ & Wang et al., 2000 \\
\hline & $\begin{array}{l}\text { T. truncatus, Sousa sp., } \\
\text { S. coeruleoalba } \\
\text { South-eastern Cape coast of South Africa }\end{array}$ & Saayman et al., 1972 \\
\hline & S. longirostris, S. attenuata, & Norris and Dohl, 1980 \\
\hline & eastern tropical Pacific, Hawaii & Norris et al., 1994 \\
\hline & & Perrin et al., 1973 \\
\hline & O. heinsohni, S. chinensis & Parra, 2006 \\
\hline & North-east Queensland, Australia & \\
\hline flat areas vs. steeper areas & $\begin{array}{l}\text { L. acutus, D. delphis, G. melas } \\
\text { Scotian shelf }\end{array}$ & Gowans and Whitehead, 1995 \\
\hline different travel routes related & O. orca (transients and residents) & Felleman et al., 1991 \\
\hline to bottom topography & British Columbia and Washington State & Morton, 1990 \\
\hline different habitat use & pongids & \\
\hline forest strata use & tree-nesting (chimpanzees) vs. & Jones and Sabater-Pi, 1971 \\
\hline & ground-nesting (gorillas) & Stanford and Nkurunung1, 2005 \\
\hline different ranging patterns/ travel routes & $\begin{array}{l}\text { P. troglodytes, G. gorilla, } \\
\text { Kahuzi-Biega NP, Democratic }\end{array}$ & $\begin{array}{l}\text { Yamagiwa et al., } 1996 \\
\text { Stanford and Nkurunungi, } 2005\end{array}$ \\
\hline & Republic of Congo & Staniora and Nkurunungi, 2005 \\
\hline association & dolphins & \\
\hline rarely or not observed & O. orca (transients and residents) & Morton, 1990; Baird and Dill, 1995 \\
\hline & British Columbia and Washington State & Barrett-Lennard et al., 1996 \\
\hline & Prince William Sound, Alaska & Saulitis et al., 2000 \\
\hline & D. delphis, D. capensis & Bearzi, 2003, 2005a \\
\hline & California & \\
\hline & D. delphis, T. truncatus & Politi et al., 1998 \\
\hline & Kalamos Island, Greece & \\
\hline observed & $\begin{array}{l}\text { T. truncatus and T. aduncus } \\
\text { Chinese waters }\end{array}$ & Wang et al., 2000 \\
\hline & S. longirostris, $S$. attenuata & Norris and Dohl, 1980 \\
\hline & eastern tropical Pacific, Hawaii & Norris et al., 1994 \\
\hline & & Perrin et al., 1973 \\
\hline & T. truncatus, Sousa sp. & Saayman et al., 1972 \\
\hline & South-eastern Cape coast of South Africa & \\
\hline & Orcaella brevirostris, & Kreb and Budiono, 2005 \\
\hline & Neophocaena phocaenoides, S. longirostris, & \\
\hline & S.l. roseiventris, T. truncatus, T. aduncus, & \\
\hline & S. attenuata, Pseudorca crassidens, Peponoce & hala electra \\
\hline & Berau Archipelago and coast off East Kalimar & an, Indonesia \\
\hline association & pongids & \\
\hline observed & P. troglodytes and G. gorilla & Kuroda et al., 1996 \\
\hline & Ndoki Forest, Republic of Congo & Stanford and Nkurunungi, 2005 \\
\hline & Bwindi Impenetrable National Park, Uganda & \\
\hline aggression & dolphins & \\
\hline rarely or not observed & O. orca (transients and residents) & Baird and Dill, 1995 \\
\hline & British Columbia and Washington State & \\
\hline & T. truncatus, Sousa sp. & Saayman et al., 1972 \\
\hline & South-eastern Cape coast of South Africa & \\
\hline
\end{tabular}




\begin{tabular}{|c|c|c|}
\hline & $\begin{array}{l}\text { D. delphis, D. capensis, T. truncatus } \\
\text { California }\end{array}$ & Bearzi, 2005a \\
\hline & D. delphis, T. truncatus & Politi and Bearzi, pers. comm. \\
\hline & Kalamos Island, Greece & \\
\hline \multirow[t]{11}{*}{ observed } & T. truncatus, $P$. phocoena & Ross and Wilson, 1996 \\
\hline & Moray Firth, Scotland & Patterson et al., 1998 \\
\hline & L. obliquidens, $P$. phocoena & Baird, 1998 \\
\hline & San Juan Island, Washington State & \\
\hline & S. frontalis, T. truncatus & Herzing et al., 2003 \\
\hline & Great Bahama Bank, Bahamas & \\
\hline & S. longirostris, $S$. attenuata & Psarakos et al., 2003 \\
\hline & Hawaii (eastern tropical Pacific) & \\
\hline & G. griseus, S. coeruleoalba & Frantzis and Herzing, 2002 \\
\hline & Gulf of Corinth, Greece & \\
\hline & $\begin{array}{l}\text { D. delphis, G. griseus, G. melaena } \\
\text { California }\end{array}$ & Shane, 1995 \\
\hline aggression & pongids & \\
\hline \multirow[t]{3}{*}{ not observed } & P. troglodytes and G. gorilla & Yamagiwa et al., 1996 \\
\hline & Kahuzi-Biega NP, Democratic & Stanford and Nkurunungi, 2005 \\
\hline & Republic of Congo & \\
\hline \multirow{10}{*}{$\begin{array}{l}\text { dietary divergence within habitat } \\
\text { different prey preference }\end{array}$} & dolphins & \\
\hline & O. orca (transients and residents) & Bigg et al., 1990 \\
\hline & British Columbia, Alaska and Washington State & Saulitis et al., 2000 \\
\hline & Felleman et al.,1991 & \\
\hline & D. delphis, T. truncatus & Ferretti et al., 1998 \\
\hline & Kalamos Island, Greece & Politi et al., 1998 \\
\hline & Tursiops sp. (two forms) & Hale et al., 2000 \\
\hline & various areas around the world & \\
\hline & D. delphis, S. coeruleoalba & Das et al., 2000 \\
\hline & North-east Atlantic & \\
\hline \multirow[t]{6}{*}{ diet overlap/ slightly different diet } & D. delphis, D. capensis & Bearzi, 2003,2005a \\
\hline & California & \\
\hline & L. acutus, D. delphis, G. melas & Gowans and Whitehead, 1995 \\
\hline & Scotian shelf & \\
\hline & L. acutus, D. delphis & Selzer and Payne, 1988 \\
\hline & continental shelf of the northeastern United State & \\
\hline \multirow[t]{5}{*}{ diet overlap/different seasons or time } & L. acutus, D. delphis, G. melas & Gowans and Whitehead, 1995 \\
\hline & Scotian shelf & \\
\hline & S. longirostris, S. attenuata & Norris and Dohl, 1980 \\
\hline & eastern tropical Pacific, Hawaii & Norris et al., 1994 \\
\hline & $\begin{array}{l}\text { S. longirostris, } S . \text { attenuata } \\
\text { eastern tropical Pacific }\end{array}$ & Perrin et al., 1973 \\
\hline dietary divergence within habitat & pongids & \\
\hline \multirow[t]{6}{*}{ diet overlap/slightly different diet and seasons } & P. troglodytes and G. gorilla & Tutin and Fernandez, 1984, 1993 \\
\hline & Lopé, Gabon, Kahuzi-Biega National Park, & Yamagiwa et al., 1996 \\
\hline & Democratic Republic of Congo, & Jones and Sabater-Pi, 1971 \\
\hline & Rio Muni, Bwindi Impenetrable & Stanford and Nkurunungi, 2005 \\
\hline & National Park, Uganda & \\
\hline & Ndoki Forest, Republic of Congo & Stanford, 2001; Kuroda et al., 1996 \\
\hline
\end{tabular}

the possibility exists that chimpanzee-gorilla foraging differ at least to avoid direct competition for food and other resources. Such a divergence may have been facilitated by the tendency of chimpanzees to adopt a far-ranging foraging strategy that relies on their ability to remember the locations and timings of ripe fruit patches from seasons and even years past. Even though many more field studies have been conducted on dolphin sympatric ecology than have been done on African apes, we have less detailed ecological information about their associations. However, the socioecology of at least some species shows striking parallels to those of African apes (Marino, 1996, 1998; Reiss et al., 1997). 
Although apes and dolphins are only distantly related, the ecological convergence of the way in which food resources are shared when two or more species are in sympatry is striking. The behavioural flexibility associated with switching prey items and foraging patterns, and coordinating these dynamics with a sympatric species, characterizes both primates and dolphins. This behavioural flexibility may contribute to avoidance of interspecific food competition. Further studies focusing on behavioural ecology in each taxon may elucidate the role of social adaptations that allow multiple species of each group to co-exist.

\section{Acknowledgements}

The manuscript was improved through review by J. Moore, W. Hamner, G. Bearzi, M. Scott, J. Mann, D. Kreb, V. Nijman and one anonymous reviewer. M. Bearzi's research was supported by Ocean Conservation Society, The UCLA Mentor Research Program Fellowship and The Coastal Environmental Quality Graduate Fellowship. Special thanks to C. Saylan, Trimble Navigation, and ESRI. C. Stanford gratefully acknowledges the support of the Uganda Wildlife Authority, the Ugandan National Council for Science and technology, and the Institute of Tropical Conservation and its staff. C.S. expresses his gratitude for the funding support of the Fulbright Foundation (C.I.E.S.), The L.S.B. Leakey Foundation, The National Geographic Society, The Wenner Gren Foundation, and The Faculty Research Fund of the University of Southern California.

\section{References}

Acevedo-Gutierrez A. 1997. Group feeding in bottlenose dolphins at Isla del Coco, Costa Rica: inter-specific interactions with prey and other hunters. Ph.D. Dissertation. Texas AandM University, College Station, TX.

Anderson D, Nordheim E, Moermond T, Gone Bi Z, Boesch C. 2005. Factors influencing tree phenology in the Taï National Park, Côte d'Ivoire. Biotropica 37: 631-640.

Anderson D, Nordheim E, Boesch C. 2006. Environmental factors influencing the seasonality of estrus in chimpanzees. Primates 47: 43-50.

Au DWK, Perryman WL. 1985. Dolphin habitats in the eastern tropical Pacific. Fishery Bulletin 83: 623-643.

Au DWK, Perryman WL, Perrin, WF. 1979. Dolphin distribution and the relationship to environmental features in the eastern tropical Pacific. National Marine Fisheries Service, Southwest Fisheries Center Administrative Report, La Jolla, CA, LJ-79-43.

Baird RW. 1994. Foraging behaviour and ecology of transient killer whales (Orcinus orca). Ph.D. Dissertation, Simon Fraser University, Burnaby, B.C.
Baird RW. 1998. An interaction between Pacific white-sided dolphins and a neonatal porpoise. Mammalia 62: 129-134.

Baird RW. 2000. The killer whales. In: Mann J, Connor RC, Tyack PL, Whitehead H (eds.). Cetacean Societies: Field Studies of Dolphins and Whales. Chicago. The University of Chicago Press: 127-153.

Baird RW, Abrams PA, Dill LM. 1992. Possible indirect interactions between transient and resident killer whales: implications for the evolution of foraging specializations in the genus Orcinus. Oecologia: 89: 125-132.

Baird RW, Dill LM. 1995. Occurrence and behaviour of transient killer whales; seasonal and pod-specific variability, foraging behaviour and prey handing. Canadian Journal of Zoology 73: 1300-1311.

Baird RW, Dill LM. 1996. Ecological and social determinants of group size in transient killer whales. Behavioural Ecology 7: 408-416.

Baird RW, Whitehead H. 2000. Social organization of mammaleating killer whales: group stability and dispersal patterns. Canadian Journal of Zoology 78: 2096-2105.

Baird RW, Ligon AD, Hooker SK, Gorgone AM. 2001. Subsurface and nighttime behaviour of pantropical spotted dolphins in Hawai'i. Canadian Journal of Zoology 79: 988-996.

Balcomb KC, Boran JR, Heimlich SL. 1982. Killer whales in greater Puget Sound. Report of the International Whaling Commission 32: 681-685.

Ballance LT, Pitman RL. 1998. Cetaceans of the western tropical Indian Ocean: Distribution, relative abundance, and comparisons with cetacean communities of two other tropical ecosystems. Marine Mammal Science 14: 429-459.

Banks RC, Brownell RL. 1969. Taxonomy of the common dolphins of the eastern Pacific Ocean. Journal of Mammology 50: 262-272.

Barrett-Lennard LG, Ford JFB, Heise KA. 1996. The mixed blessing of echolocation: Differences in sonar use by fisheating and mammal-eating killer whales. Animal Behaviour 51: 553-565.

Bearzi M. 2003. Behavioral ecology of the marine mammals of Santa Monica Bay, California. Ph.D. dissertation, University of California, Los Angeles, CA.

Bearzi M. 2005a. Habitat partitioning by three species of dolphins in Santa Monica Bay, CA. Southern California Academy of Science Bulletin 104:113-124.

Bearzi M. 2005b. Dolphin sympatric ecology. Marine Biology Research 1: 165-175.

Bearzi M. 2005c. Aspects of the ecology and behaviour of bottlenose dolphins (Tursiops truncatus) in Santa Monica Bay. California. Journal of Cetacean Resource Management 7: 75-83.

Bearzi G, Politi E, Notarbartolo di Sciara G. 1999. Diurnal behaviour of free-ranging bottlenose dolphins in the Kvarnerić (northern Adriatic Sea). Marine Mammal Science 15: 10651097.

Bearzi G, Politi E, Agazzi S, Bruno S, Costa M., Bonizzoni S. 2005. Occurrence, site fidelity and the present status of coastal dolphins (Delphinus delphis and Tursiops truncatus) in the eastern Ionian Sea. Aquatic Conservation: Marine and freshwater Ecosystems 15: 243-257. 
Bel'kovich VM, Ivanova EE, Yefremenkova OV, Kozarovitsky LB, Kharitonov SP. 1991. Herd structure, hunting, and play. Bottlenose dolphins in the Black Sea. In: Pryor K, Norris KS (eds.): Dolphin Societies. Berkeley: University of California Press: 17-18.

Benoit-Bird KJ, Au WWL. 2003. Prey dynamics affect foraging by a pelagic predator (Stenella longirostris) over a range of spatial and temporal scales. Behavioural Ecology and Sociobiology 53: 364-373.

Bigg MA. 1982. An assessment of killer whales (Orcinus orca) stocks off Vancouver Island, British Columbia. Report of the International Whaling Commission 32: 655-666.

Bigg MA, Ellis GM, Ford JKB, Balcomb III KC. 1987. Killer Whales: A Study of Their Identification, Genealogy, and Natural History in British Columbia and Washington State. Nanaimo, BC: Phantom Press.

Bigg MA, Olesiuk PF, Ellis GM, Ford JKB, Balcomb III KC. 1990. Social organization and genealogy of resident killer whales (Orcinus orca) in the coastal waters of British Columbia and Washington State. In: Hammond PS, Mizroch SA, Donovan GP (eds.). Individual Recognition of Cetaceans: Use of Photo-Identification and other Techniques to Estimate Population Parameters. Reports of the International Whaling Commission, Special Issue 12, International Whaling Commission, Cambridge, UK: 383-405.

Boesch C, Boesch-Achermann H. 2000. The Chimpanzees of the Taï Forest: Behavioural Ecology and Evolution. Oxford: Oxford University Press.

Bruno S, Politi E, Bearzi G. 2004. Social organization of a common dolphin community in the eastern Ionian Sea: Evidence of a fluid fission-fusion society. European Research on Cetaceans 15: 243-275.

Calvert JJ. 1985. Food selection by western lowland gorillas $(G$. g. gorilla) in relation to food chemistry. Oecologia 65: 236246.

Chapman CA, White FJ, Wrangham RW. 1994. Party size in chimpanzees and bonobos: A re-evaluation of theory based on two similarly forested sites. In: Wrangham RW, McGrew WC, de Waal FBM, Heltne PG (eds.). Chimpanzee Cultures. Cambridge: Harvard University Press: 41-57.

Cockcroft VG, Peddemors VM. 1990. Seasonal distribution and density of common dolphins Delphinus delphis off the southeast coast of southern Africa. South African Journal of Marine Science 9: 371-377.

Conklin-Brittain NL, Knott CD, Wrangham RW. 2006. Energy intake by wild chimpanzees and orangutans: methodological considerations and a preliminary comparison. In: Hohmann G, Robbins MA, Boesch C (eds). Feeding Ecology in Apes and Other Primates. Cambridge: Cambridge University Press: 445-465.

Connor RC, Smolker RA. 1985. Habituated dolphins (Tursiops sp.) in western Australia. Journal of Mammalogy 66: 398400.

Connor RC, Smolker RA, Richards AF. 1992. Dolphin alliances and coalitions. In: Harcourt AH, de Waal FBM (eds). Coalitions and Alliances in Humans and other Animals. Oxford University Press: 415-443.
Connor RC, Mann J, Tyack PL, Whitehead H. 1998. Social evolution in toothed whales. Trends in Ecology and Evolution 13: 228-232.

Connor RC, Wells RS, Mann J, Read AJ. 2000a. The bottlenose dolphin: social relationships in a fission-fusion society. In: Mann J, Connor RC, Tyack PL, Whitehead H (eds.). Cetacean Societies: Field Studies of Dolphins and Whales. Chicago: The University of Chicago Press: 91-126.

Connor RC, Read A, Wrangham R. 2000b. Male reproductive strategies and social bonds. In: Mann J, Connor RC, Tyack PL, Whitehead H (eds.). Cetacean Societies: Field Studies of Dolphins and Whales. Chicago: The University of Chicago Press: 247-269.

Connor RC, Heithaus MR, Barre LM. 2000c. Complex social structure, alliance stability and mating access in a bottlenose dolphin super-alliance. Proceeding of the Royal Society of London B 268: 263-267.

Coppens Y. 1994. East side story: the origin of humankind. Scientific American 270: 62-79.

Dahlheim ME, Heyning JE. 1999. Killer whale Orcinus orca. In: Ridgway S, Harrison Sir R. (eds.). Handbook of Marine Mammals. Vol. 6, The Second Book of Dolphins and Porpoises. San Diego: Academic Press: 281-322.

Das K, Lepoint G, Loizeau V, Debacker V, Dauby P, Bouquegneau JM. 2000. Tuna and dolphin associations in the northeast Atlantic: evidence of different ecological niches from stable isotopes and heavy metal measurements. Marine Pollution Bulletin 40: 102-109.

Defran RH, Weller DW, Kelly DL, Espinosa MA. 1999. Range characteristics of Pacific coast bottlenose dolphins (Tursiops truncatus) in the Southern California Bight. Marine Mammal Science 15: 381-393.

Delgado RA, van Schaik CP. 2000. The behavioural ecology and conservation of the orangutan (Pongo pygmaeus): a tale of two islands. Evolutionary Anthropology 9: 201-218.

de Waal FB, Tyack PL. 2003. Animal Social Complexity: Intelligence, Culture, and Individualized Societies. Cambridge, MA: Harvard University Press.

Dolar MLL. 1999. Abundance, distribution and feeding ecology of small cetaceans in the eastern Sulu Sea and Tañon Strait, Philippines. Ph.D. dissertation, University of California, San Diego, CA.

Doran DM, McNeilage A. 1998. Gorilla ecology and behaviour. Evolutionary Anthropology 6: 120-131.

Dunbar RIM. 1988. Primate Social Systems. Ithaca, NY: Comstock Publishing Company.

Evans WE. 1975. Distribution, differentiation of populations, and other aspects of the natural history of Delphinus delphis Linnaeus in the northeastern Pacific. Ph.D. Dissertation, University of California, Los Angeles, CA.

Evans WE. 1994. Common dolphin, white-bellied porpoise Delphinus delphis Linnaeus, 1758. In: Ridgway SH, Harrison Sir R. (eds.). Handbook of Marine Mammals. Vol. 5. Orlando: Academic Press: 191-224.

Felleman FL, Heimlich-Boran JR, Osborne RW. 1991. The feeding ecology of killer whales (Orcinus orca) in the Pacific northwest. In: Prior K, Norris KS (eds.). Dolphin Societies: 
Discoveries and Puzzles. Berkeley. University of California Press: 113-147.

Ferretti S, Bearzi G, Politi E. 1998. Comparing behaviour of inshore bottlenose and common dolphins in the eastern Ionian Sea through focal group surfacing pattern analysis. European Research on Cetaceans 12: 209.

Finch CE, Stanford CB. 2004. Meat-adaptive genes and the evolution of slower aging in humans. Quarterly Review of Biology 79: 1-50.

Fitch JE, Brownell RL Jr. 1968. Fish otoliths in cetacean stomachs and their importance on interpreting food habits. Journal of the Fisheries Research Board of Canada 25: 25612574.

Ford JKB, Ellis GM, Barrett-Lennard LG, Morton AB, Palm RS, Balcomb III KC. 1998. Dietary specialization in two sympatric populations of killer whales (Orcinus orca) in coastal British Columbia and adjacent waters. Canadian Journal of Zoology 76: 1456-1471.

Fossey D, Harcourt AH. 1977. Feeding ecology of free-ranging mountain gorillas (Gorilla gorilla beringei). In: CluttonBrock TH (ed.). Primate Ecology: Studies of Feeding and Ranging Behaviour in Lemurs, Monkeys and Apes. London: Academic Press: 415-447.

Frantzis, A, Herzing D. 2002. Mixed-species associations of striped dolphins (Stenella coeruleoalba), short-beaked common dolphins (Delphinus delphis) and Risso's dolphins (Grampus griseus) in the Gulf of Corinth (Greece, Mediterranean Sea). Aquatic Mammals 28: 188-197.

Furuichi T. 1987. Sexual swelling, receptivity, and grouping of wild pygmy chimpanzee females at Wamba, Zaïre. Primates 28: 309-318.

Futuyma DJ. 1997. Evolutionary Biology. Sunderland, MA: Sinauer Associates, Inc.

Garcia S, Knouse D, Sagarminaga R, Cañadas A. 2000. An insight on the biological significance of mixed groups of common dolphins (Delphinus delphis) and striped dolphins (Stenella coeruleoalba) in the Alboran Sea. In: Evans PGH, Pitt-Aiken R, Rogan E. (eds). European Research on Cetaceans 14: 135-137.

Goldsmith ML. 1999. Ranging behaviour of a lowland gorilla (Gorilla g. gorilla) group at Bai Hokou, Central African Republic. International Journal of Primatology 20: 1-23.

Goodall J. 1986. The Chimpanzees of Gombe: Patterns of behaviour. Cambridge, UK: Harvard University Press.

Gowans S, Whitehead H. 1995. Distribution and habitat partitioning by small odontocetes in the Gully, a submarine canyon on the Scotian Shelf. Canadian Journal of Zoology 73: 1599-1608.

Guinet C. 1990. Sympatrie des deux categories d'orques dans le Detroit de Johnstone, Columbie Britannique. Revue d'Ecologie (Terre et Vie) 45: 25-34.

Hale PT, Barretto AS, Ross GJB. 2000. Comparative morphology and distribution of the aduncus and truncatus forms of bottlenose dolphin Tursiops in the Indian and western Pacific Oceans. Aquatic Mammals 26: 101-110.

Hansen LJ. 1990. California coastal bottlenose dolphins. In: Leatherwood S, Reeves RR. (eds.). The Bottlenose Dolphin. San Diego: Academic Press: 403-420.
Harcourt AH. 1978. Strategies of emigration and transfer by primates, with particular reference to gorillas. Zeitschrift für Tierpsychologie 48: 401-420.

Harcourt AH, Fossey D, Sabater-Pi J. 1981. Demography of Gorilla gorilla. Journal of Zoology 195: 215-233.

Heyning JE, Perrin WF. 1994. Evidence for two species of common dolphins (genus Delphinus) from the eastern north $\mathrm{Pa}-$ cific. Contributions in Science 442: 1-35.

Herman LM. 1980. Cognitive characteristics of dolphins. In: Herman LM. (ed.). Cetacean behaviour: Mechanisms and Functions. New York: Wiley-Interscience: 363-429.

Herzing DL, Johnson CM. 1997. Interspecific interactions between Atlantic spotted dolphins (Stenella frontalis) and bottlenose dolphins (Tursiops truncatus) in the Bahamas, 19851995. Aquatic Mammals 23: 85-99.

Herzing DL, Moewe K, Brunnick BJ. 2003. Interspecific interactions between Atlantic spotted dolphins (Stenella frontalis) and bottlenose dolphins (Tursiops truncatus) on Great Bahama Bank, Bahamas. Aquatic Mammals 23: 335-341.

Hill PS, Barlow J. 1992. Report of a marine mammal survey of the California coast aboard the research vessel McArthur July 28-November 5, 1991. NOAA Technical Memorandum NMFS-SWFSC-169, 103.

Hobbs MJ. 2004. Habitat partitioning in common dolphin (Delphinus delphis) and striped dolphin (Stenella coeruleoalba) in the western English Channel and Bay of Biscay. Master's thesis, University of Wales, Bangor, UK. Department of Marine Mammal Science.

Hoelzel AR. 1998. Genetic structure of cetacean populations in sympatry, parapatry, and mixed assemblages: implications for conservation policy. The Journal of Heredity 89: 451458.

Houle A. 2004. Mechanisms of co-existence among the frugivorous primates of Kibale National Park, Uganda. Ph.D. Dissertation, Université du Quebec á Montréal.

Hui CA. 1979. Undersea topography and distribution of dolphins of the genus Delphinus in the Southern California Bight. Journal of Mammology 60: 521-527.

Johnson CM, Herzing DL. 2006. Primate, cetacean and pinniped cognition compared: an introduction. Aquatic Mammals 32: 409-412.

Jones C, Sabater-Pi J. 1971. Comparative ecology of Gorilla gorilla (Savage and Wyman) and Pan troglodytes (Blumenbach) in Rio Muni, Wwest Africa. Bibliotheca Primatologica 13: 1-95.

Kano T. 1992. The Last Ape. Stanford, CA: Stanford University Press.

Klinowska M. 1991. Dolphins, Porpoises and Whales of the World. The IUCN Red Data Book. Gland: IUCN.

Kreb D, Budiono. 2005. Cetacean diversity and habitat preferences in tropical waters of East Kalimantan, Indonesia. Raffles Bulletin of Zoology 53: 149-155.

Kuroda S. 1992. Ecological interspecies relationships between gorillas and chimpanzees in the Ndoki-Nouabale Reserve, northern Congo. In: Itoigawa N, Sugiyama Y, Sackett GP, Thompson RKR (eds.). Topics in Primatology. Volume 2: behaviour, Ecology, and Conservation.Tokyo: Tokyo University Press: 385-394. 
Kuroda S, Nishihara T, Suzuki S, Oko R. 1996. Sympatric chimpanzees and gorillas in the Ndoki Forest, Congo. In: McGrew WC, Marchant LF, Nishida T. (eds.). Great Ape Societies. Cambridge: University Press: 71-81.

Leatherwood S, Reeves RR, Foster L. 1983. The Sierra Club Handbook of Whales and Dolphins. City, CA: Sierra Club Books.

Leatherwood S, Reeves RR, Perrin WF, Evans WE. 1988. Whales, Dolphins, and Porpoises of the Eastern North Pacific and Adjacent Waters: A Guide to Their Identification. New York, NY: Dover Publications.

Lefebvre L, Marino L, Sol D, Lemieux-Lefebvre S, Arshad S. 2006. Large brains and lengthened life history periods in odontocetes. Brain, Behaviour and Evolution 68: 218-228.

Magliocca F, Querouil S. 1997. Preliminary report on the use of the maya-maya north saline (Odzala National Park, Congo) by lowland gorillas. Gorilla Conservation News 11: 5 .

Mais F. 1974. Pelagic fish surveys in the California current. California Department of Fish and Game Fish Bulletin 162: $1-79$.

Malenky RK, Kuroda S, Vineberg E, Wrangham RW. 1994. The significance of terrestrial herbaceous foods for bonobos, chimpanzees, and gorillas. In: Wrangham RW, McGrew WC, de Waal FBM, Heltne PG (eds.). Chimpanzee Cultures. Harvard: Harward University Press: 59-76.

Marino L. 1996. What can dolphins tell us about primate evolution? Evolutionary Anthropology 5: 3-110.

Marino L. 1998. A comparison of encephalization between odontocete cetaceans and anthropoid primates. Brain Behavioral Evolution 51: 230-238.

McCowan B, Marino L, Vance E, Walker L, Reiss D. 2000. Bubble ring play of bottlenose dolphins (Tursiops truncatus): implications for cognition. Journal of Comparative Psychology 114: 98-106.

Mitani JC, Watts D. 1999. Demographic influences on the hunting behaviour of chimpanzees. American Journal of Physical Anthropology 109: 439-454.

Morgan D, Sanz C. 2006. Chimpanzee feeding ecology and comparisons with sympatric gorillas in the Goulalougo Triangle, Republic of Congo. In: Hohmann G, Robbins MA, Boesch, C (eds). Feeding Ecology in Apes and Other Primates. Cambridge: Cambridge University Press: 97-122.

Morton AB. 1990. A quantitative comparison of the behaviour of resident and transient forms of the killer whale off the central British Columbia coast. In: Hammond PS, Mizroch SA, Donovan GP (eds.). Individual Recognition of Cetaceans: Use of Photo-Identification and other Techniques to Estimate Population Parameters. Reports of the International Whaling Commission, Special Issue 12. Cambridge: International Whaling Commission: 245-248.

Mussi B, Miragliuolo A, Bearzi G. 2002. Short-beaked common dolphins around the island of Ischia, Italy (southern Tyrrhenian Sea). European Research on Cetaceans 16: 15.

Neumann DR. 2001a. Seasonal movements of short-beaked common dolphins (Delphinus delphis) in the north-western Bay of Plenty, New Zealand: influence of sea surface temperature and El Niño/La Niña. New Zealand Journal of Marine and Freshwater Research 35: 371-374.
Neumann DR. 2001b. The activity budget of free-ranging common dolphins (Delphinus delphis) in the northwestern Bay of Plenty, New Zealand. Aquatic Mammals 27: 121-136.

Nishida T. 1979. The social structure of chimpanzees of the Mahale Mountains. In: Hamburg DA, McCown ER. (eds). The Great Apes. Menlo Park: Benjamin/Cummings: 72-122.

Nishihara T. 1992. A preliminary report on the feeding habits of western lowland gorilla (Gorilla gorilla gorilla) in the Ndoki Forest of northern Congo. In: Itoigawa N, Sugiyama Y, Sackett GP, Thompson RKR. (eds). Topics in Primatology. Volume 2. Behaviour, Ecology, and Conservation. Tokyo: University of Tokyo Press: 225-240.

Nishihara T. 1995. Feeding ecology of western lowland gorilla in the Nouabale-Ndoki National Park, Congo. Primates 36: 151-168.

Nkurunungi JB. 2005. Feeding and ranging ecology of gorillas (Gorilla gorilla beringei) in Bwindi Impenetrable National Park. Ph.D. Dissertation, Makerere University, Kampala, Uganda.

Norris KS, Prescott JK. 1961. Observations on Pacific cetaceans of Californian and Mexican waters. Zoology 63: 291-402.

Norris KS, Dohl TP. 1980. The structure and function of cetacean schools. In: Herman LM. (ed). Cetacean behaviour: Mechanisms and Functions. New York: John Wiley and Sons: 211-261.

Norris KS, Würsig B, Wells RS, Würsig M. 1994. The Hawaiian Spinner Dolphin. Berkely, CA: University of California Press.

Olejniczak C. 1996. Update on the Mbeli Bai gorilla study in the Nouabale-Ndoko National Park, northern Congo. Gorilla Conservation News 10: 5-8.

Parra G. 2006. Resource partitioning in sympatric delphinids: space use and habitat preferences of Australian snubfin and Indo-Pacific humpback dolphins. Journal of Animal Ecology 75: 862-874.

Patterson IAP, Reid RJ, Wilson B, Grellier K, Ross HM, Thompson PM. 1998. Evidence for infanticide in bottlenose dolphins; an explanation for violent interactions with harbour porpoise? Proceedings of The Royal Society of London B 265: $1167-1170$.

Perrin WF, Warner RR, Fiscus CH, Holts DB. 1973. Stomach contents of porpoise, Stenella spp., and yellowfin tuna, Thunnus albacares, in mixed-species aggregations. Fishery Bulletin 71: 1077-1092.

Perrin WF, Scott MD, Walker GJ, Cass VL. 1985. Review of geographical stocks of tropical dolphins (Stenella spp. and Delphinus delphis) in the eastern Pacific. NOAA Technical Report NMFS 28: 1-28.

Perrin WF, Mesnick SL. 2003. Sexual ecology of the spinner dolphins, Stenella longirostris: geographical variation in mating system. Marine Mammal Science 19: 462-483.

Pianka ER. 1978. Evolutionary Ecology. Harper and Row, New York, NY.

Polacheck T. 1987. Relative abundance, distribution and interspecific relationship of cetacean schools in the eastern tropical Pacific. Marine Mammal Science 3: 54-77.

Politi E. 1998. Un progetto per i delfini in Mediterraneo. Le Scienze 360: 64-69. 
Politi E, Airoldi S, Natoli A, Frantzis A. 1998. Unexpected prevalence of common dolphins over sympatric bottlenose dolphins in eastern Ionian sea inshore waters. European Research on Cetaceans 12: 120.

Pruetz JD. 2006. Feeding ecology of savanna chimpanzees (Pan troglodytes verus) at Fongoli, Senegal. In: Hohmann G, Robbins MA, Boesch C. (eds). Feeding Ecology in Apes and Other Primates. Cambridge: Cambridge University Press: 161-182.

Psarakos S, Herzing DL, Marten K. 2003. Mixed-species associations between pantropical spotted dolphins (Stenella attenuata) and Hawaiian spinner dolphins (Stenella longirostris) off Oahu, Hawaii. Aquatic Mammals 29: 390-395.

Reichard UH. 2003. Social Monogamy in Gibbons: the Male Perspective. In: Reichard UH, Boesch C. (eds). Monogamy: Mating Strategies and Partnerships in Birds, Humans and other Mammals. Cambridge, Cambridge University Press: 190-213.

Reiss D, McCowan B, Marino L. 1997. Communicative and other cognitive characteristics of bottlenose dolphins. Trends in Cognitive Sciences 1: 123-156.

Remis MJ. 1994. Feeding ecology and positional behaviour of western lowland gorillas (Gorilla g. gorilla) in the Central African Republic. Ph.D. Dissertation, Yale University.

Remis MJ. 1997. Ranging and grouping patterns of a western lowland gorilla group at Bai Hokou, Central African Republic. American Journal of Primatology 43: 111-133.

Rendell L, Whitehead H. 2001. Culture in whales and dolphins. Behavioral and Brain Sciences 24: 309-382.

Robbins MM, Nkurunungi JB, McNeilage A. 2006. Variability of the feeding ecology of eastern gorillas. In: Hohmann G, Robbins MA, Boesch C. (eds). Feeding Ecology in Apes and Other Primates. Cambridge: Cambridge University Press: 25-47.

Rogers ME, Williamson EA. 1987. Density of herbaceous plants eaten by gorillas in Gabon: Some preliminary data. Biotropica 19: $278-281$.

Rogers ME, Williamson EA, Tutin CEG, Fernandez M. 1988. Effects of the dry season on gorilla diet in Gabon. Primate Report: Selected Proceedings of the XIIth IPS-Congress 22: 25-33.

Rogers ME, Maisels F, Williamson EA, Fernandez M, Tutin CEG. 1990. Gorilla diet in the Lopé Reserve, Gabon: A nutritional analysis. Oecologia 84: 326-339.

Rosel PE, Dizon AE, Heyning JE. 1994. Genetic analysis of sympatric morphotypes of common dolphins (genus Delphinus). Marine Biology 119: 159-167.

Ross GJB. 1977. The taxonomy of bottlenosed dolphins Tursiops in south African waters, with notes on their biology. Annals of the Cape Provence Museum of Natural History 11(9): 135-194.

Ross HM, Wilson B. 1996. Violent interactions between bottlenose dolphins and harbour porpoises. Proceedings of the Royal Society of London B 263: 283-286.

Roughgarden J. 1976. Resource partitioning among competing species: A coevolutionary approach. Theoretical Population Biology 9: 388-424.

Saayman GS, Bower D, Tayler CK. 1972. Observations on inshore and pelagic dolphins on the south-eastern cape coast of south Africa. Koedoe 15: 1-24.
Sabater-Pi J. 1977. Contribution to the study of alimentation of lowland gorillas in the natural state in Rio Muni, Republic of Equatorial Guinea (W. Africa). Primates 18: 183-204.

Sabater-Pi J, Groves C. 1972. The importance of the higher primates in the diet of the Fang in Rio Muni. Man 7: 239-243.

Sagarminaga R, Cañadas A. 1995. Studying a possible competition for ecological niche between the common dolphin, Delphinus delphis, and striped dolphin, Stenella coeruleoalba, along the southeastern coast of Spain. European Research on Cetaceans 9: 114-117.

Sagarminaga R, Cañadas A. 1998. A comparative study on the distribution and behaviour of the common dolphin (Delphinus delphis), and the striped dolphin (Stenella coeruleoalba) along the south-eastern coast of Spain. European Research on Cetaceans 12: 436.

Samuels A, Gifford T. 1997. A quantitative assessment of dominance relations among bottlenose dolphins. Marine Mammal Science 13: 70-99.

Saulitis E, Matkin C, Barrett-Lennard L, Heise K, Ellis G. 2000. Foraging strategies of sympatric killer whales (Orcinus orca) populations in Prince William Sound, Alaska. Marine Mammal Science 16: 94-109.

Schwartz M, Hohn A, Bernard H, Chivers S, Peliter K. 1992. Stomach contents of beach cast cetaceans collected along the San Diego County coast of California, 1972-1991. Southwest Fisheries Science Center Administrative Report LJ-92-18: 33.

Scott MD, Wells RS, Irvine AB. 1990. A long term study of bottlenose dolphins on the west coast of Florida. In: Leatherwood S, Reeves RR. (eds). The Bottlenose Dolphin. San Diego: Academic Press: 235-244.

Scott MD, Cattanach KL. 1998. Diel patterns in aggregations of pelagic dolphins and tunas in the eastern Pacific. Marine Mammal Science 14: 401-428.

Selzer LA, Payne PM. 1988. The distribution of white-sided (Lagenorhynchus acutus) and common dolphins (Delphinus delphis) vs. environmental features of the continental shelf of the northeastern United States. Marine Mammal Science 4: $141-153$

Shane SH. 1995. Relationship between pilot whales and Risso's dolphins at Santa Catalina Island, California, USA. Marine Ecology Progress Series 123: 5-11.

Similä T, Ugarte F. 1993. Surface and underwater observations of cooperatively feeding killer whales in northern Norway. Canadian Journal of Zoology 71: 1494-1499.

Smolker RA, Richards AF, Connor RC, Mann J, Berggren P. 1997. Sponge-carrying by Indian Ocean bottlenose dolphins: possible tool-use by a delphinid. Ethology 103: 454-465.

Sommer V, Reichard U. 2000. Rethinking monogamy: the gibbon case. In: Kappeler PM (Ed). Primate Males. Causes and Consequences of Variation in Group Composition. Cambridge: Cambridge University Press: 159-168.

Stanford CB. 1998. Chimpanzee and Red Colobus: The Ecology of Predator and Prey. Harvard: Harvard University Press.

Stanford CB. 1999. The Bwindi-Impenetrable Great Ape Project: progress report for 1999. Gorilla Conservation News 13: 13.

Stanford CB. 2001. A comparison of social meat-foraging by chimpanzees and human foragers. In: Stanford CB, Bunn H. 
(eds). Meat-eating and Human Evolution. Oxford: Oxford University Press: 122-140.

Stanford CB. 2006. The sympatric ecology of African great apes, with implications for the hominoid divergence. Primates 47: 91-101.

Stanford CB, Nkurunungi JB. 2003. Sympatric ecology of chimpanzees and gorillas in Bwindi Impenetrable National Park, Uganda. Diet. International Journal of Primatology 24: 901-918.

Stewart K, Harcourt S. 1987. Gorillas: variation in female relationships. In: Smuts BB, Cheney DL, Seyfarth RM, Wrangham RW, Struhsaker TT. (eds). Primate Societies. Chicago: University of Chicago Press: 155-164.

Sussman RL. 1984. The Pygmy Chimpanzee. New York: Plenum Press.

Suzuki S, Nishihara T. 1992. Feeding strategies of sympatric gorillas and chimpanzees in the Ndoki-Nouabalé forest, with special reference to co-feeding behaviour by both species. In: Rapport Annuel 1991-1992. Recherches Scientifiques Cooperatives par les Equipes Japonaises et Congolaises. Tokyo: University of Tokyo Press: 28-33.

Symington MM. 1987. Ecological and social correlates of party size in the black spider monkey, Ateles paniscus chamek. Ph.D. Dissertation, Princeton University, New Jersey.

Tayler CK, Saayman GS. 1972. The social organization and behaviour of dolphins (Tursiops aduncus) and baboons (Papio ursinus): some comparisons and assessments. Annals of the Cape Provence Museum of Natural History 9: 11-49.

Te Bockhorst IJA, Hogeweg P. 1994. Self-structuring in artificial 'chimps' offers new hypotheses for male grouping in chimpanzees. Behaviour 130: 229-252.

Tutin CEG. 1979. Mating patterns and reproductive strategies in a community of wild chimpanzees (Pan troglodytes schweinfurthii). Behavioural Ecology and Sociobiology 6: 29-38.

Tutin CEG. 1996. Ranging and social structure of lowland gorillas in the Lopé Reserve, Gabon. In: McGrew WC, Marchant LF, Nishida T. (eds). Great Ape Societies. Cambridge: Cambridge University Press: 58-70.

Tutin CEG, Fernandez M. 1984. Nationwide census of gorilla (Gorilla g. gorilla) and chimpanzee populations in Gabon. American Journal of Primatology 6: 313-336.

Tutin CEG, Fernandez M. 1985. Foods consumed by sympatric populations of Gorilla $g$. beringei and Pan t. troglodytes in Gabon: Some preliminary data. International Journal of Primatology 6: 27-43.

Tutin CEG, Fernandez M. 1993. Composition of the diet of chimpanzees and comparisons with that of sympatric lowland gorillas in the Lopé Reserve, Gabon. American Journal of Primatology 30: 195-211.

Tutin CEG, Fernandez M, Rogers ME, Williamson EA. 1992. A preliminary analysis of the social structure of lowland gorillas in the Lopé Reserve, Gabon. In: Itoigawa N, Sugiyamam Y, Sackett GP, Thompson RKR. (eds). Topics in Primatology, Vol. 2: behaviour, Ecology, and Conservation. Tokyo: University of Tokyo Press: 245-254.

Tutin CEG, Ham RM, White LJT, Harrison MJS. 1997. The primate community of the Lopé Reserve, Gabon: Diets, responses to fruit scarcity, and effects on biomass. American Journal of Primatology 42: 1-24.
Van Schaik CP. 2004. Among Orangutans. Cambridge: Harvard University Press.

Wang JY, Chou LS, White BN. 1999. Mitochondrial DNA analysis of sympatric morphotypes of bottlenose dolphins (genus Tursiops) in Chinese waters. Molecular Ecology 8: 16031612.

Wang JY, Chou LS, White BN. 2000. Osteological differences between two sympatric forms of bottlenose dolphins (genus Tursiops) in Chinese waters. Journal of Zoology London 252: $147-162$.

Watts DP. 1984. Composition and variability of mountain gorilla diets in the central Virungas. American Journal of Primatology 7: 323-356.

Watts DP. 1991. Strategies of habitat use by mountain gorillas. Folia Primatologica 56: 1-16.

Watts DP. 1996. Comparative socio-ecology of gorillas. In: McGrew WC, Marchant LF, Nishida T. (eds). Great Ape Societies. Cambridge: Cambridge University Press: 16-28.

Weaver AC. 1987. An ethogram of naturally occurring behaviour of bottlenose dolphins, Tursiops truncatus, in southern California waters. Master's Thesis, San Diego State University, CA.

Weller DW. 1991. The social ecology of Pacific coast bottlenose dolphins. Master's Thesis, San Diego State University, CA.

Wells RS. 1991. The role of long-term study in understanding the social structure of a bottlenose dolphin community. In: Pryor K, Norris KS. (eds). Dolphin Societies: Discoveries and Puzzles. Berkeley: University of California Press: 199-225.

Wells RS, Scott MD, Irvine AB. 1987. The social structure of free-ranging bottlenose dolphins. Current Mammalogy 1: 247-305.

Whitehead H, Rendell L, Osborne RW, Würsig B. 2004. Culture and conservation of non-humans with reference to whales and dolphins: review and new directions. Biological Conservation 120: 431-441.

Whiten A, Goodall J, McGrew WC, Nishida T, Reynolds V, Sugiyama Y, Tutin CEG, Wrangham RW, Boesch C. 1999. Cultures in chimpanzees. Nature 399: 682-685.

Williamson EA. 1988. Behavioural ecology of western lowland gorillas in Gabon. Ph.D. Dissertation, University of Stirling, Scotland.

Williamson EA, Tutin CEG, Rogers ME, Fernandez M. 1990. Composition of the diet of lowland gorillas in Gabon. American Journal of Primatology 21: 265-277.

Wilson B. 1995. The ecology of bottlenose dolphins on the Moray Firth, Scotland: a population at the northern extreme of the species' range. Ph.D. Disseration, University of Aberdeen, Scotland.

Wilson B, Thompson P, Hammond P. 1993. An examination of the social structure of a resident group of bottlenosed dolphins (Tursiops truncatus) in the Moray Firth, N.E., Scotland. In: Evans PGH. (ed). European Research on Cetaceans: Proceedings of the Seventh Annual Conference of the European Cetacean Society, European Cetacean Society, Cambridge, UK: 114-115.

Wrangham RW. 1977. Feeding behaviour of chimpanzees in Gombe National Park, Tanzania. In: Clutton-Brock TH. (ed). Primate Ecology: Studies of Feeding and Ranging Be- 
haviour in Lemurs, Monkeys and Apes. London: Academic Press: 504-538.

Wrangham RW, McGrew WC, de Waal FBM, Heltne PG, Eds. 1994. Chimpanzee Cultures. Harvard: Harvard University Press.

Würsig B. 1978. Occurrence and group organization of Atlantic bottlenose porpoises (Tursiops truncatus) in an Argentine bay. Biological Bulletin 154: 348-359.

Würsig B. 1986. Delphinid foraging strategies. In: Schusterman RJ, Thomas JA, Wood FG. (eds). Dolphin Cognition and behaviour: A Comparative Approach. Hillsdale: Lawrence Erlbaum Association: 347-359.

Yamagiwa J. Basabose AK. 2006. Effects of fruit scarcity on foraging strategies of sympatric gorillas and chimpanzees. In: Hohmann G, Robbins MA, Boesch C. (eds). Feeding Ecology in Apes and Other Primates. Cambridge: Cambridge University Press: 73-96.

Yamagiwa J, Mwanza N, Spangenberg A, Maruhashi T, Yumoto T, Fischer A, Steinhauer-Bukart B. 1993. A census of the eastern lowland gorillas Gorilla gorilla graueri in KahuziBiega National Park with reference to mountain gorillas G.g. beringei in the Virunga region, Zaïre. Biological Conservation 64: 83-89.
Yamagiwa J, Mwanza N, Yumoto T, Maruhashi T. 1994. Seasonal change in the composition of the diet of eastern lowland gorillas. Primates 35: 1-14.

Yamagiwa J, Maruhashi T, Yumoto T, Mwanza N. 1996. Dietary and ranging overlap in sympatric gorillas and chimpanzees in Kahuzi-Biega National Park, Zaïre. In: McGrew WC, Marchant LF, Nishida T. (eds). Great Ape Societies. Cambridge: Cambridge University Press: 82-98.

Yang HC. 1976. Studies on the whales, porpoises and dolphins of Taiwan. Annual Report of the Science Taiwan Museum (Taipei) 19: 131-178.

Young DD, Cockroft VG. 1994. Diet of common dolphins (Delphinus delphis) off the south-east coast of southern Africa: Opportunism or specialization? The Zoological Society of London 234: 41-53.

Zhou K, Qian W. 1985. Distribution of the dolphins of the genus Tursiops in the China Seas. Aquatic Mammals 1: 16-19.

Received: 5 March 2007

Accepted: 24 September 2007 